\title{
10 SOME REMARKS ON PLACENAMES IN THE FLINDERS
}

\author{
Bernhard Schebeck
}

\section{1 'DESCRIPTIVE NAMES': A CURSORY ANALYSIS OF A SAMPLE'}

The Northern Flinders Ranges are the home of the Adnya-mathanha people, 'the people of the rocky hills', whose language is related to the Kaurna language of the Adelaide Plains. The cursory analysis presented here is based on a sample of 483 placenames in the Flinders Ranges.

This number is subject to the understanding that it is not always clear whether two entries are really two names or rather two 'spellings' of the same name. But for the present brief survey I simply ignore such questions. I shall also disregard the question of 'one versus two words', for instance spellings such as Idhiawi versus Idhi Awi. This might appear to be a minor decision, but I shall briefly argue below that the decision of what is a genuine name is perhaps not so clear-cut.

Of these 483 names I have assigned 139, almost one-third of the total, to the 'descriptive class'. In order of frequency I have found the following:

\subsection{Names containing awi 'water'}

41 end in -awi 'water'. These names represent almost one-third of the 'descriptive class':

5 end in awi urtu 'waterhole'. So, this is quite a small subclass.

3 (or perhaps 4 ) begin with awi 'water'. So, this too is a small subclass.

\footnotetext{
This paper is a sequel to the research of Hercus and Potezny (1999). In mid-1999 I wrote a letter to Luise Hercus, in which I made some comments on this article, whereupon I was encouraged to work those remarks into a paper. This is the result. I wish to thank Luise Hercus also for providing me with a draft copy of her contribution to the present volume.

Due to external circumstances, my own material is not fully accessible to me and, therefore, the bulk of the examples is drawn from what is known through the publications of other people, mainly John McEntee and Dorothy Tunbridge. My own recordings are still only partially accessible to me at the time of writing. In other words, if an explanation given to me is quoted here, this is done only from memory.
}

L. Hercus, F. Hodges and J. Simpson, eds, The Land is a Map: placenames of Indigenous origin in Australia, 140-153. Canberra: Pandanus Books for Pacific Linguistics, 2002.

(C) Bernhard Schebeck 


\subsection{Names containing vari 'creek'}

(including one name ending in -parinha):

22 end in vari or vari-nha 'creek'. That is, over 15 per cent of the 'descriptive class'.

\subsection{Names containing vambata 'hill'}

20 end in vambata 'hill'. That is, over 14 per cent of the 'descriptive class'.

This means that between them these three subclasses comprise about two-thirds of the descriptive class entries. The numbers in the remaining subclasses are quite small and for several of them there is just a single entry. Only the following two subclasses surpass 5 per cent of the total.

\subsection{Names containing inbiri 'gap'}

(irnbiri 'gorge, gully', in McEntee and McKenzie 1992):

8 end in inbiri/irnbiri 'gap; gully, gorge'.

\subsection{Names containing urtu 'hole'}

7 end in urtu 'hole'. If the 5 names listed above as ending in awi urtu 'water-hole' are included, then the number is 12 , i.e. still less than 10 per cent.

For the sake of completeness, I list the remaining subclasses with the numbers of entries given in brackets:

ending in

$\begin{array}{ll}\text { ithapi/ithipi } & \text { 'hole, hollow, cave' (4) } \\ \text { warldu } & \text { 'saddle' (4) } \\ \text { yurru } & \text { 'range, ridge' (4) } \\ \text { adnya } & \text { 'stone, rock' (3) } \\ \text { vitana/vithana } & \text { 'plain, flat' (3) } \\ \text { madapa } & \text { 'valley' (2) } \\ \text { mati/marti } & \text { 'hillside, slope' (2) } \\ \text { wami } & \text { 'bend in creek' (2) } \\ \text { yukari } & \text { 'rock wall' (2) }\end{array}$

The rest are found in only one name each, specifically:

ending in

$\begin{array}{ll}\text { itala/itarla } & \text { 'hole; crack, gap' } \\ \text { manyi } & \text { 'slate; regosol, coarse sand' } \\ \text { murrka } & \text { 'stony slope, steep scree' } \\ \text { n(h)iirri / n(h)iarri } & \text { 'side, edge (of cliff)' }\end{array}$




$\begin{array}{ll}\text { vinki(r)ti / virngarti-nha } & \text { 'junction (of a road), fork (in a creek)' } \\ \text { warru } & \text { 'red clay' } \\ \text { yaurru / yaurra } & \text { 'peak, pointed hill' }\end{array}$

It is clear that the -awi names fit into this wider pattern of compound names. There are still other similar compound names, which do not quite fall into this category.

First of all, there are names containing a term denoting a natural species - be it flora (mainly wida 'river red gum', but also arlku 'black oak') or fauna (mainly urdlu 'red kangaroo'). Often the species name is the first element, but not always, for instance:

\section{Nharni wida-nha \\ 'Mathewson's Spring and Creek' \\ Urlkambarra-nha-madlha 'mallee patch behind Wayarl-aralya', both mentioned by McEntee and McKenzie (1992:32). ${ }^{2}$}

One may or may not include here names containing Akurru/Akurra 'the mythical Rainbow Serpent'. ${ }^{3}$ In this case the decision of whether it is a 'name' or not is particularly difficult, because of the notion of an akurru awi 'serpent water(hole)', presumably one created, but not necessarily inhabited, by the serpent.

In this context I take up again the question of what is 'really a name'. Often we find a name, and also that name with the addition of a natural feature word such as 'creek', 'hill', etc. Tunbridge (1988:161) has the name Adlyundunha and also Adlyundunha Awi 'Alioota Bore' as well as Adlyundunha Vari 'Alioota Creek', and many others; sometimes it is unclear whether the occurrences of a name with and without a given natural feature word refer to the same place or not. Thus we find Irrakanha, which McEntee (1992:22) gives as 'Erragoona Hill', but Tunbridge (1988:162) as 'The John Waterhole', for which she also has Irrakanha Awi 'The John Waterhole'; McEntee however lists Irrakanha Vari 'Big John Creek at Wertaloona'. Therefore a certain amount of 'fusion' may be required for a compound to qualify as a 'name': it may be more than sheer accident that of all the compound names those ending in -awi are particularly frequent in English (i.e. names in '-owie'). A more complete list of names would be required for further study of this and similar questions.

\section{A FEW FURTHER COMMENTS ON THIS FIRST ANALYSIS}

As already hinted in the last paragraph, this analysis poses a certain number of questions, of which the following three are singled out for further comment:

\footnotetext{
From here on this work is referred to briefly as 'McEntee'.

3 Note that Tunbridge consistently writes akurra, where Andrew Coulthard with whom I worked always recorded akurru. C.P. Mountford's spellings 'acaru' and 'arcaru' and the English placename Arkaroola, quoted by both McEntee and Tunbridge, hint at a pronunciation 'akarru'. This is but one example of minor variations in my own recordings and those made by Tunbridge and, perhaps to a lesser degree, by $\mathrm{J}$. McEntee. However, these variations do not appear to be important enough to deserve the label 'dialectal', and I prefer to speak of 'family traditions'.
} 

a) What is a placename?
b) What is a descriptive placename?
c) What is the meaning of a placename?

\subsection{What is a placename?}

This question is of course by no means peculiar to the region under consideration. Some brief comments on various categories of placenames are given here. ${ }^{4}$

\subsection{1 'General terms'}

A general term, such as for instance the word for 'river', may function as a placename, as in the case of the Diamantina/Warburton being called simply Karla, i.e. 'The Creek' by the Simpson Desert Wangkangurru people. ${ }^{5}$ No similar example seems to have been reported from the Flinders Ranges - unless we take the very name Adnyamathanha as an indication that Adnya 'stone, hill' may have functioned as a sort of name for 'The Ranges', or, alternatively, it may hint at a case where 'a general term is used because there IS no specific term' (Hercus, in the present publication), a decision which I find difficult to make.

\subsection{2 'Intermediate' names}

There are no clear reports in the Flinders Ranges of names of the type Hercus calls 'Intermediate', in which a feature characterising a given place indicates the locality to people who are already 'in the know'. However, a term such as for instance Arlku vari 'Black Oak Creek' (Tunbridge 1988) may be, or originally have been of such an 'intermediate' type. The above-mentioned expression akurru awi, which also appears as the 'name' Akurra Awi in Tunbridge (1988:161), is doubtlessly a serious candidate for this type, as there are said to be many akurru awis. Unfortunately we do not know enough about the use of this expression in daily speech; but some of the recorded texts do indeed hint at such 'intermediate' usage.

\footnotetext{
4 There do not appear to be any placenames in the Flinders based on possible misunderstandings of the type listed by Hercus as 'silly names'. see however Hercus and Potezny (1999:175), about the reported misunderstanding concerning the 'name' Wundowie. Although this paper is specifically about placenames, I may point out here that the name 'Nimbalda', found in Smith (1879:87) for the language of the Adnyamathanha people, is probably of this type: nimba 'such' plus arlda, an archaic word for 'language'. In this context we may mention the expression Yura ngawarla. This, I suspect under the guidance of European linguists, has in recent years become quite fashionable as the name for the language of the Adnyamathanha people, whereas the older term Adnyaarlda is practically forgotten today. The new term is akin to this type - although, as I have argued elsewhere, it is based on a certain carelessness rather than outright misunderstanding.

5 As an example from English, compare 'The Gap' in Alice Springs.
} 


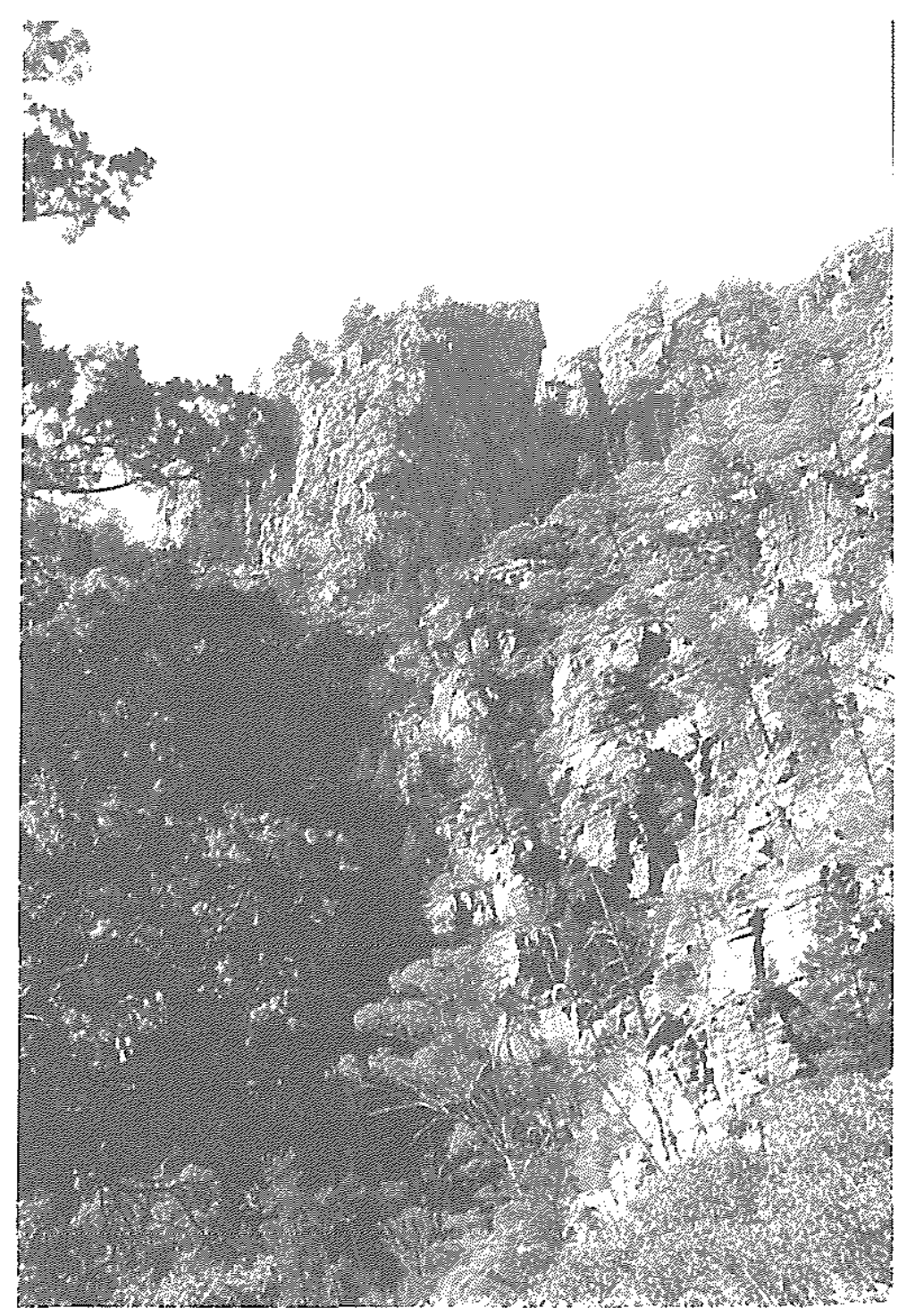

Figure 1: Edeowie Gorge. Idhiawi Inbiri. Photo: D. Kelly

\subsection{3 'Derivative' names}

What may be called a 'derivative' type results from the addition of a general term such as for instance 'creek', 'waterhole', 'gap', 'saddle', or whatever, to a placename. ${ }^{6}$ Thus, besides the

6 The orthography of such names calls for comment: why write for example Wakarla-udnanha Inbiri 'Waukawoodna Gap', but Murdlu Udnanha 'a big hill', 'Murdlu's droppings', as is done in Tunbridge (1988:164), rather than Wakarla Udnanha Inbiri or Murdlu-udnanha? My guess is that this somewhat haphazard treatment is reflected in the corresponding transcribed 'English' names, e.g. 'Waukawoodna' versus cases where there is no explicit reference as in 'big hill', or cases where there is a partial translation, as in 'Balcanoona Creek' for Wildya Vari. The treatment appears to be capricious and no clear reason is manifest for variations even within the same publication as, for instance, Urta Awi 'Weetowie Waters, and spring above' and Urtaawi 'a spring' in Tunbridge (1988:166); not to mention variations between authors, comparable to other types of variations in orthography, e.g. Itarl-awi 'Italowie' (McEntee 1992:19)) as against Ithala Awi 'Italowie Well' (Tunbridge, 1988:162). To come to some clearer conclusion on this, one 
name Idhiawi(nha) (Tunbridge 1988:162 writes Idhi Awi, 'Edeowie') we also find the name Idhiawi Inbiri which may be interpreted either as the expression 'the gap at Edeowie' or, alternatively, as the name 'Edeowie Gorge'. In Tunbridge (1988) several series of such 'names' appear as for instance Adlyundunha, Adlyundunha Awi, and Adlyundunha Vari. Clearly, Adlyundunha Awi 'Alioota Bore' differs in formation from Idhiawi 'Edeowie' (lit. 'Finch water'), just as Adlyundunha Vari differs in formation from Wildya Vari 'creek branch flowing into Balcanoona Creek', (lit. 'Night/darkness Creek'): there are no independent placenames *Idhi(nha) or *Wildya(nha) - not that such simple formations are unknown in the area. But how do we decide whether a given 'name' belongs to this 'derivative' type or not? For instance, the link between Valdhanha 'Beltana' and Valdha Marti 'name of rock face in the Mount Serle area' (Tunbridge 1988:166) is purely linguistic (cf. valdha 'rug; clothes'), there is no geographical nor, as far as can be ascertained, any mythological link. Therefore, we may decide that Valdha Marti (lit. 'Rugs Slope'), is a 'genuine placename', rather than one of the 'derivative' type; this decision is considerably strengthened by the fact that there is a mythological explanation for that name (see $\$ 2.2$ below). I do not have any ready answers to such questions.

\subsubsection{Secondary names}

What may be called 'secondary' names are not 'official' names, but rather allusions, they resemble the 'intermediate names', discussed above. However, in this case, the allusion is usually to a story. For instance, Mount Serle has the 'official' name Atuwarapanha, but it is said to 'be' Wildu the eagle, because of the associated story. Therefore, if the word Wildu 'Eagle' may be extended to be used as a reference to the place, as if it were a placename, we would have such a 'secondary' usage. A name such as Kilawila may belong to this category: in the myth of Mount Termination (Kakalpunha, in Kuyani country) Kilawila is the name of the killer of the cannibal Papurdityirdityi. The cannibal is said to 'be' the larger of the two main hills of Mount Termination, while Kilawila is said to 'be' the smaller hill.

\subsection{What is a 'descriptive' placename?}

The 'descriptive class' discussed above is nothing more than a selection of names that contain a word for a natural feature of the landscape but not, for instance, those names which contain words for a natural species. A name such as Ithala Awi/Itarl-awi 'Italowie' (Tunbridge/McEntee) 'lit. hole-water', i.e. water running through a hole or gap in the rocks, may reasonably be accepted as delivering a sort of general and vague description of the place. A name such as Idhi Awi 'Edeowie', 'Finch water' - presumably because finches came

could invoke stress patterns, but this might not deliver clear-cut decisions. On the other hand, we could say that 'derivative' names should be written as two words, and 'genuine names' as a single word. Thus, we would have Valdhamarti rather than Valdha Marti. However, if it turned out that a 'genuine name' decision can be justified, would everybody be happy, for instance, with the orthography Idhiawiirnbiri? The main drawback of such a suggestion has to do with the fact that the orthographic decision would depend on the semantic interpretation which may be uncertain.

7 Tunbridge here refers to Tunbridge 1988. 
there to drink - may lack descriptive power, because finches may well drink from other waterholes in the area, and because this feature may not always be evident. Similarly Adata Madapa 'Nepabunna Valley', explained by Tunbridge (1988:161) as 'Frost Valley', will reveal its alleged distinctive feature only at certain times, without necessarily appearing unique. On the other hand, the meaning of the above-mentioned name Valdha Marti 'Rugs Slope' remains totally obscure if one is unaware of the mythological reference. Finally, what is presumably a description might prove quite ephemeral, as the landscape changes: I am thinking of a name such as Arladu-vuyuvuyunha, explained to me by A. Coulthard as meaning 'tea-trees all twisted/torn into pieces', which would rather hint at the final stages of existence of the defining feature of the description.

The use of the term 'descriptive' in the examples discussed is therefore appropriate only in the sense that the name contains the word of the natural feature, such as 'Hill', 'Gap', 'Creek', 'Waterhole/Pond', etc. which it names. And, as we have already seen, it is this very characteristic - namely a sort of 'self-reference', to somewhat abuse an important concept which raises the general question of 'is it a name at all?'

\subsection{What is the meaning of a name?}

First of all, it will be noticed that in Adnyamathanha, the natural feature word, when present, usually appears at the end of the name. ${ }^{8}$ It is often preceded by some other word which appears to qualify or perhaps better, specify the following term - no matter what the allusion in that 'qualification' - as for instance in the names quoted in fn. 9: Warturli Widanha (lit. 'ringneck parrot gum tree'), as against Vira Widanha (lit. 'moon gum tree'). Such interpretations can be definitive only in those cases where the first word can be linked to the known vocabulary of the language. Even if such a link is established, the 'meaning' is not always obvious: while a literal meaning may be established, a clear reference is not always available. In many cases, sheer guesswork will establish a 'meaning'. Thus, for instance, in the case of Adata Madapa 'Frost Valley' we may establish a 'meaning' by guessing that winters are particularly severe in that valley, or at least that the valley has that reputation, a little like 'Clare Valley' in the area west of Adelaide. Similarly, we may guess that the name Idhi Awi 'Finch Water' hints at the idea that this is a favourite spot for finches; and so on. However, in the absence of clear information on this, all these remain just guesses.

The case of Valdha Marti 'Rugs Slope' is different: either we run out of guesses altogether, or we will resort to highly implausible or 'contrived' ones; we can grasp the reference only by discovering the story, in which an Ancestor pegs out wallaby rugs valdha for drying on that slope marti. The example of Adlyundyanha 'Mundy Waters' in fn 10 is probably similar although the presence of myrtle trees may have contributed to the naming.

This distinction between literal meaning and reference shows that there are "layers of meaning" to be considered. Furthermore, there is also the problem of how reliable a given interpretation by a 'native speaker' is, especially in the case of more complex formations. Thus the hill or range called Wayalayala/Wayarlayarla was explained to me by Andrew

\footnotetext{
As already pointed out by Hercus and Potezny (1999:177), there are some exceptions to this.

9 Moreover, in the case of mythological references at least, we may never be sure of how many layers there are or were! Thus, for example, I know of at least one 'deeper' reference of the repeatedly quoted name Valdha Marti.
} 
Coulthard as a derivation of the verb wayali- 'to turn (around)', hence as meaning something like 'twisted in all directions': i.e. it was ultimately interpreted as a simple description of the shape of this geological formation. By contrast, McEntee (1992:113) explains it literally as a contraction of a reduplicated form of wayu-warla 'shelter-break', but gives no further information as to what this refers to. This example clearly shows that an explanation by a native speaker cannot necessarily be relied upon as 'the correct interpretation'. Apart from cases of popular etymology, where the literal meaning has simply been forgotten, there may also be sheer ad hocery, especially when 'informants' are pressed for answers under the assumption that there must be a simple answer and that it must be known to them. Although the threat of re-analysis by popular etymology or sense-making can never be fully excluded, we do certainly stand on much firmer ground where the meaning is embedded in a traditional story, as in the example of Valdha Marti mentioned above. This fact shows just how deficient our knowledge of many placenames really is.

Therefore, in the absence of deeper knowledge, we simply have to fall back on literal meanings - vulnerable to misinterpretation as they may be. Such literal analyses will often be able to come up with only a partial answer. Thus the name Adlyundyanha 'Mundy Waters' can be partially translated by the word adlyu 'myrtle tree', ${ }^{10}$ while the remainder of the name cannot be linked to any known lexeme. A similar remark applies to the name Adlyundunha, given in Tunbridge (1988:161) and many others. Whereas the difficulty of translation strengthens the status as a 'real name', the lack of analysis may call into question the correctness of the recording. Thus the name for 'Mount Serle' has been recorded as Atuwarapanha by myself and by J. McEntee, whereas Tunbridge (1988:161) has Arta-wararlpanha/Artawararlpanha. Although we may say that two recordings weigh more than one, the absence of any further analysis of the name adds to our uncertainty. ${ }^{11}$

\section{A FEW FURTHER SUGGESTIONS}

I propose to discuss a few types of names containing some special morphemes or, in the last case, a special construction.

10 Adlyundyanha 'Mundy Waters' (recorded from Andrew Coulthard) does not refer to myrtle trees, adlyu, nor, as one might think to 'a place with myrtle trees'. It refers to a place 'where an Ancestor's myrtle spear went down'. Similarly Warturli Widanha 'Mount Lyndhurst' (McEntee 1992:108) presumably does not refer to a gum tree, but to a place where it stands or once stood; nevertheless such self-references are not necessarily absent in this type of name. The entry in Tunbridge (1988:70), Vira Widanha 'gum tree in Wilpena Creek', appears to attest to this. Thus, our attempts to discover clear rules are frustrated yet again.

11 Notice also the name 'Batuarapunna' in Taplin (1879:87), which is identified there with Mount Freeling. If it is correct to link this name with the one under discussion, then the apparent dropping (rather than 'weakening' to v-) of the initial B- remains unexplained, whereas the reference to Mount Freeling would appear to be due to 'mis-identification' rather than to a historic change of identification. Such a change appears unlikely, because of the relatively short period of time between the report in Taplin and those of others, such as for instance N. Tindale (who writes in his diary 'Artu|warapana'), and also because of the considerable importance attached to Mount Serle by Adnyamathanha people.

I have never been tempted to link the first part of that name to the word artu 'woman'. I do not know whether or not Tunbridge had in mind a link with arta 'grass tree'. Without speculating any further about the (literal) meaning of this name, it must be pointed out that the transcriptions alone imply the hypothesis that the second term begins with the syllable wa-, rather than with a- as would be possible in the case of the spelling 'Batuarapunna' reported in Taplin. 


\subsection{Names in -pi-nha}

First of all, back to the names ending in -awi(-nha) which, after all, triggered the comments made in the present paper. Hercus and Potezny (1999) point out that there are two forms for 'water', namely -awi and -api, and that the second variant form is apparently totally absent in Adnyamathanha. However, it may be suggested that the few placenames ending in -pi-nha are formed with -api. The three names that appear in publications on Adnyamathanha are:

$\begin{array}{lll}\text { Mudlhapinha } & \text { Mudlapina Gap/Mudlapena Spring } & \begin{array}{l}\text { (McEntee 1992:89), } \\ \text { (Tunbridge 1988:163) }\end{array} \\ \text { Tharrapinha } & \text { Terrapinna Waterhole } & \text { (McEntee 1992:48) } \\ \text { Thudupinha } & \text { waterhole west of Var-ardlanha } & \text { (McEntee) 1992:49) } \\ \text { Arkaroola: hill near Freeling Heights } & \text { (Tunbridge 1988:167) }\end{array}$

Although there is no agreement on the identification of the places (namely 'Gap' as against 'Spring' in the first case, and 'waterhole' as against 'hill' in the last case), a reference to some source of water appears to be at least implied. From the semantic angle the interpretation of -pi- as -api 'water' appears plausible. This interpretation seems to be strengthened by the existence of the name Api Yakunha 'spring near Yadnina (Balcanoona)', given by McEntee (1992:9), with the rare appearance of the word for 'water' at the beginning of the name. We would however have to admit that there is a higher degree of fusion than in the names ending in -awi, as can be seen by the contrast between Thudupinha and the name which was pronounced as Muruawi by Andrew Coulthard, but is recorded as Mur-awi 'Moorowie Mount Chambers' by McEntee (1992:90) rather than *Muruwi. The contrast is confirmed also by the different stress pattern: in my own experience, all names in -awi have the secondary stress on the first syllable of -awi, ${ }^{12}$ whereas all three names in -pi-nha have the secondary stress on the syllable -pi-. Therefore, if we accept the interpretation of the three names as containing the variant form -api 'water', we must concede that the degree of fusion is so high as to have obscured that link probably even to the speakers. If all this is correct, it would suggest that these names, which are unlikely to be borrowings, are archaic forms.

There are some further names which at first sight might appear to fall into this category, but for which another explanation is readily available. The name Wakarl-apina 'Grindstone Range' is explained by McEntee as 'lit. mob of crows', and Yarnmarr-apinha 'hill west of Nepabunna' as 'lit. mob of steps' by McEntee, and Yanmarri-apinha 'Nepabunna: stepped hill' as 'several steps' by Tunbridge (1988:171). ${ }^{13}$ Warturlipinha 'Angepena Station: hill' (Tunbridge, 1988:124) is explained by McEntee as Warturl-ipi Yurru 'Range north side of Angepena-Nepabunna road, Mount Constitution, lit. 'Ringneck parrot egg'. Tunbridge (1988:124) gives warturli-vipi 'ring-neck parrot's egg'. These interpretations appear quite plausible: in the present context they highlight the risks of misinterpretation.

12 It will be noticed that Andrew Coulthard's pronunciation, as just reported, differs from that reported by McEntee in that Andrew Coulthard usually did not drop the last vowel of the word preceding -awi.

13 It is interpreted as containing the plural marker, which is given as the 'suffix' -apinha by those two authors (also as -aipinha/-aipina by some present-day literate native speakers): it was rendered as the 'particle' vapina/vapinha by myself. 


\subsection{Names in -pa-nha}

Names in -pa-nha appear to parallel those in -pi-nha, because of the stress pattern (secondary stress on the syllable -pa-), the presence of the suffix -nha, ${ }^{14}$ and probably a certain degree of 'fusion'. The best known is Nhipa-pa-nha 'Nepabunna'. I would guess that at least some of these names are old diminutives, that is old compounds with the word vapa 'little, small'. In spite of the presence of variants such as Akurrupanha 'hill on NE side of Ngurru Widlya' (Tunbridge 1988:15) and Akurrupanha 'pad going through gap near Mount Serle' (McEntee 1992:2 and Tunbridge1988:161), we cannot be sure how far the fusion has gone.

Again we have names which at first may appear to belong here, but which clearly have a different explanation. Thus, McEntee's Andupanha 'Silver Gap' (1992:8) appears at first sight to belong here (with fusion); however, the variant form Anduupanha, which was recorded by Tunbridge as well as by myself, supports the literal translation 'white wallaby' given by several speakers from andu 'rock wallaby' + upa 'white'. There are still other cases which clearly do not belong here: Tunbridge's explanation (1988:170) of the name Yamuti Ardupanha 'Wirrealpa: two ridges near Red Well' as 'Yamuti married couple' is quite plausible, and the name Yulupanha 'Uliban Yulupanha Spring' (Tunbridge 1988:171) is no doubt a 'simple' name, derived from yulhupa 'for a long time'.

\subsection{Names in -aka-nha}

There are not many placenames in this group, the best known is 'Patsy Springs', given as Mudlh-akanha by McEntee, and as Mudlhaakanha by Tunbridge (1988:163). Austin et al. (1976) have suggested the translation 'fruit' for the word aka, but I had previously suggested 'little piece, bit'. ${ }^{15}$ Words like mayaaka 'wild pear' seem to fit the 'fruit' interpretation well. The form minaaka 'eye', perhaps more particularly 'pupil' (McEntee 1992:84) besides mina 'eye', was the topic of the 1976 paper. There are other uses, which do not so obviously conform to the interpretation 'fruit', such as the expression inda/indha aka 'end of a rock', recorded by Andrew Coulthard. It was the existence of a particle aka-nha, that is -aka followed by the suffix - nha, which was the main reason for my suggesting a lexical meaning 'little piece, bit'; therefore, the meaning 'fruit' may be a secondary development. The particle -aka-nha is used in a way similar to English 'one', as in inha aka-nha 'this one'. ${ }^{16}$

\footnotetext{
14 We cannot generalise to the point of declaring the suffix -nha obligatory in these names. Thus we find the variants Wartapanha 'Spring in Weetootla Gorge (Wortupa)' (McEntee 1992:108) and Wartapa 'Wortupa Spring' (Tunbridge (1988:169); for this name see $\$ 3.4$ below). There is also, for instance, Widap-awi 'Spring in Bendieuta Creek' (McEntee) and Widapa Awi 'Widapawi Creek: waterhole (at Wirrealpa Station)' (Tunbridge 1988:170), and no variant with the suffix -nha.

15 In Schebeck (1974:14-15, 47), this is called, somewhat infelicitously, a 'classifier'. I am leaving aside the use of a suffix -(a)ka- to distinguish female from male 'baby names', as in marru 'big; wide; fourth born boy', marruana 'fourth born boy', as against marruka(nha) 'fourth born girl', which I now do not directly link with the morpheme under discussion.

16 McEntee distinguishes two suffixes -aka, one glossed as 'fruit (attached to nouns?)', and the other as 'piece, bit (attached to adjectives?)'; he also lists a suffix -akanha, which he glosses as 'that piece'. All these are distinguished in his dictionary from an archaic noun aka, glossed as 'head'.
} 


\subsection{Names in -wata-nha / -warta-nha}

There is another 'classifier', which can be written -warta-nha, as in inha warta-nha yakarti 'this (one) child'. It is unclear how this is derived, but there is a word warta, glossed by McEntee (1992:108) as '1. bush; 2. large, big', and by Tunbridge (1988:122) as 'one, thing (or sometimes, big)'. The word does, indeed, occur in compounds with the meaning 'big' as in warta vurdli 'morning star', explained as 'big star' by Tunbridge. The interpretation as 'tree' is found in igawarta 'wild orange tree' given to me by Andrew Coulthard. It is not always clear which interpretation should be adopted. However, in several names the translation as 'big' (or even the translation 'one') will do. Perhaps the best-known name of this kind is Mudlu-warta-nha/Mudluwartanha 'Moolawatana' (McEntee 1992:88, Tunbridge 1988:163), which McEntee indeed explains as 'lit. big hip'. The explanations with 'big' appear to work mainly for names where the element in question is the second part. For, unlike in the previous cases, there are several examples where the morpheme is the first part of a name. Probably the best known is Wartalyunha 'Wertaloona', which is listed by both McEntee and Tunbridge without further explanation. In the case of the name Wartapanha (fn. 13) 'Spring in Weetootla Gorge (Wortupa)' (McEntee 1992:108) and Wartapa 'Wortupa Spring' (Tunbridge 1988:169), the translation as 'big' is much less convincing than in previous examples and the translation by 'bush, tree' appears at least equally acceptable. It is possible that this name does not belong here at all, but is simply the word wartapa 'shadow (of a cliff)', which was recorded by the author from A. Coulthard. The difficulties of interpretation are further illustrated by the example Vityirliwartapanha 'Sliding Rock near Beltana' (McEntee 1992:64), which appears to combine the morpheme meaning, among other things, 'big' and the diminutive form. ${ }^{17}$

\subsection{A note on lexical elements}

It is not an exaggeration to say that any word may occur in a placename. Of course, there are differences in frequency and, naturally, complete absences. For instance, names containing u(r)dna 'faeces' are common, whereas umbu 'urine' is almost absent. Besides words for natural features, those referring to natural species are particularly frequent. This and similar topics require further study.

\subsection{A note on the construction of placenames}

So far we have dealt mainly with compounds as placenames. A simple word, one which consists of a single lexical item, to which the suffix -nha can be added, may also function as a placename: a few examples were given in the preceding pages. ${ }^{18}$ The statistical survey of 483

\footnotetext{
17 Whereas the first part could be interpreted as vityi 'dish, coolamon' + suffix -li 'like' (not *-rli), 'like a dish'.

18 The name pronounced as Umburratanha 'Umberatana' by Andrew Coulthard may for instance be an example; but Tunbridge gives the name as Ngambadatanha, making such an interpretation less likely. Just for information the following further examples are listed without explanation: Uldanha/Uldhanha 'Wooltana' (McEntee 1992:33, explained as 'bough'), 'Wooltana Spring' (Tunbridge 1988:166); Valdhanha 'Beltana', Yanggunha (see Hercus \& Potezny, 1999:168, with the explanation 'the left-handed one',
} 
names showed that at the most about 10.5 per cent of the total are of this type. Furthermore, all attempts to find some sort of correlation between compounding and the suffixing of -nha have failed.

As is well known, whole phrases may function as placenames; the distinguishing feature is the presence of a verb form. In our rough survey, there are 14 such names. This type interesting as it may be - is statistically insignificant. It is noteworthy that no less than 7 of these 14 names contain the intransitiviser -i-. Admittedly, a few of the verbs in question are intransitive, such as winmii- used by Andrew Coulthard when speaking to me, or wirnmi-i(McEntee 1992:120) 'to whistle', but the majority of these examples may be interpreted as 'impersonal' rather than passive. Thus, the name Wakarl-arrpa-indhanha/Wakarla Adpaindanha 'Cave in Wildu legend' 'Angepena Station: rock with cave' (Tunbridge 1988:168) is explained by McEntee (McEntee 1992:107) as 'lit. painting of crows', i.e. 'the crows being painted up'. Wabma Nambaindanha 'Aroona valley area, hill' means '(the place where) the snakes (are) being covered up'. A striking feature of this type of name is the suffixing of -nda-nha, with, it seems, obligatory use of -nha. Hence Schebeck (1974:49) has interpreted these forms as verbal nouns. There is just one name which is in the 'verbal noun' form, but does not contain the 'intransitiviser' suffix -i-, namely Yurlu Ngukandanha 'lit. kingfisher going' (Tunbridge 1988:171). There is also one name which may be interpreted as 'participle' (that is, without the suffix -nha), namely Arlarru Udu-udu-manda 'Tea-tree Shadow', explained by McEntee (1988:13) as 'lit. tea-trees pulled down'. This is the only transitive example in this class, ${ }^{19}$ and the question may be asked whether the forms in -ndha-nha/-nda-nha are obligatorily intransitive.

There are two examples of names with a finite verb form. The first might appear to belong to the previous subtype: but Nguthunanga Mai Ambatanha 'hill near Nepabunna' is explained by Tunbridge as 'the Spirits of the Dreaming cooking damper': the form is interpreted as an ergative and, therefore, the verb form must be interpreted as a present. ${ }^{20}$ The other example is Tunbridge's Akurra Avianggu 'Akurra vomited', which is grammatically transparent.

The two remaining examples are grammatically unclear, as both appear to show an otherwise unknown construction involving a verb root. The first is the name Arladu-vuyuvuyunha, quoted in $\$ 2.2$ : this name is complicated by the fact that the actual verb root vuyu- (tr) 'blow with mouth (?); clean; smoke out; twist (?)' is marked as being uncertain in meaning in my vocabulary. ${ }^{21}$ The other example appears in Tunbridge as Yurndungarlpa 'Mount Samuel' which is also unclear: it could be suggested that this is an abbreviated form of a name linked with the expression yurndu ngarlpandana-thadi "west, lit. 'towards the sun setting' (McEntee 1992:102).

whereas Tunbridge (1988) explains it as 'looking over left shoulder' (1988:98)). This shows, yet again, that the literal meaning might not be enough to fully explain a name; Yulupanha 'Uliban [Yulupanha Spring]'.

19 The verb, which McEntee (1992:13) gives as udu-ma- 'to pull down, to unpack', looks like a transitivised form, but no verb root *udu- has been recorded. For a discussion of transitivity see Schebeck (1976).

20 McEntee (1992:45) reports also a name Nguthuna Mai 'Damper Hill', so one might be tempted to interpret the above as a locative construction. However, this interpretation is vitiated by the fact that the locative of this name would be Nguthuna Mai-nga, not * Nguthuna-nga Mai.

21 McEntee (1992:73) lists only an intransitive verb vuyu-vuyu-ri- 'to be pretty and curly (as child's hair)'. 


\section{CONCLUSION}

Without wishing to appear negative I have attempted to emphasise the risks that await too hastily assembled conclusions, and to counsel caution in what is a very worthwhile line of research. Research on names, and placenames in particular, is important from a practical viewpoint - perhaps with some implications. It is also important for more theoretical reasons. It is not only in Indo-European linguistics that the study of placenames allows us to peer just a little deeper into the history of the linguistic and hence the human geography of vast areas of the land.

\section{REFERENCES}

Austin, P., R. Ellis and L.A. Hercus, 1976, 'Fruit of the eyes' semantic diffusion in the Lakes languages of South Australia. Papers in Australian Linguistics 10, 57-77. Canberra: Pacific Linguistics.

Dixon, R.M.W., ed., 1976, Grammatical Categories in Australian Languages. Canberra: Australian Institute of Aboriginal Studies.

Hercus, Luise A. and Vlad Potezny, 1999, 'Finch' versus 'finch-water': A study of Aboriginal place-names in South Australia. Records of the South Australian Museum 31 (2):165180.

McEntee, John and Pearl McKenzie, 1992, Adna-mat-na English Dictionary. Adelaide: the author.

Schebeck, B., 1974, Texts on the Social System of the Atynyamathanha People with Grammatical Notes. Canberra: Pacific Linguistics.

- 1976, Transitivity, ergativity and voice in Atjnjamathanha. In Dixon, ed., 1976:534-550.

Smith, Henry Quincy, 1879, The Nimbalda tribe (Far North). In Taplin, ed., 1879:87-89.

Taplin, G., 1879, The Folklore, Manners, Customs and Languages of the South Australian Aborigines. Adelaide: Government Printer.

Tunbridge, Dorothy, 1988, Flinders Ranges Dreaming. Canberra: Aboriginal Studies Press. 